\title{
Pengaruh Medan Magnet pada Pembawa Muatan Lapisan Klorofil Spirulina sp Hasil Spin Coating
}

\author{
Septinia Qoirun Nisa, Utari, dan Budi Purnama* \\ Jurusan Fisika, Fakultas Matematika dan Ilmu Pengetahuan Alam, \\ Universitas Sebelas Maret (UNS), Jl. Ir. Sutami 36A Kentingan, Surakarta 57126
}

Intisari

Pengaruh medan magnet pada pembawa muatan lapisan Spirulina sp hasil spin coating melalui pengukuran I-V dilaporkan pada makalah ini. Hasil pengukuran magneto konduktansi menunjukkan bahwa medan yang diperlukan untuk mencapai nilai arus terukur konstan pada sampel B lebih kecil dari sampel A. Hal ini mengindikasikan bahwa mekanisme rekombinasi pasangan pembawa muatan disumbang oleh tingkat kemurnian. Akhirnya rasio MC 37,4\% dan 50,6\% diperoleh untuk masing-masing sampel A dan sampel B.

\begin{abstract}
The magnetic field effect on the charge carrier of Spirulina $s p$ thin filmsby spin coating fabrication by mean a $\mathrm{I}-\mathrm{V}$ measurements is reported in this paper. Magnetoconductance measurements showed that the field required to achieve the saturated currentof sample B is smaller than the sample A. This indicated the mechanism of charge carrier recombination attribute to the degree of purity. Finally, a MC ratio of $37.4 \%$ and $50.6 \%$ was obtained for sample A and sample B, respectively.
\end{abstract}

KATA KUNCI: Spirulinasp, pengukuran I-V, magnetoconductance

\section{PENDAHULUAN}

Diskusi berkenaan dengan devais elektronika organik belakangan ini menjadi perbincangan hangat para fisikawan. Hal ini mengingat, dewasa ini aplikasi di bidang elektronika modern dibuat tidak hanya disumbang oleh semikonduktor konvensional berbasis bahan semikonduktor, melainkan juga dari bahan organik [1]. Terdapat ketertarikan besar pada bahan organik ini karena biaya yang murah dan mudah dalam proses pembuatan [2]. Salah satu topik hangat di bidang elektonika organic adalah efek medan magnet terhadap pembawa muatan. Telah ditemukan bahwa arus pada devais organik dapat diubah dengan cara mengaplikasikan medan magnet kecil. Efek ini mengacu pada magneto-conductance (MC) atau organic magneto-resistance (OMAR) [3]. Efek medan magnet dapat muncul pada temperatur ruang dengan kisaran medan magnet kecil yaitu kisaran mili Tesla, membuka potensi aplikasi sensor [4].

Pada makalah ini, kajian mengenai efek medan magnet terhadap pembawa muatan lapisan klorofil alam didikusikan. Lapisan klorofil alam ditumbuhkan di atas substrat $\mathrm{Cu}$ PCB berpola. Evaluasi ketergantungan pembawa muatan terhadap medan magnet pada sampel lapisan klorofil diuji dengan dengan metode I-V sistem two probe pada temperatur ruang.

\footnotetext{
*E-MAIL: bpurnama@mipa.uns.ac.id
}

\section{METODOLOGI}

Tahapan yang dilakukan untuk membuat larutan Spirulina $s p$ yaitu ekstraksi, evaporasi dan kromatografi mengikuti prosedur sebelumnya [5]. Pada tahap ekstraksi, dilakukan pelarutan serbuk Spirulina $s p$ dengan aceton (p.a.). Untuk 1 gram bubuk Spirulina $s p$ dilarutkan dengan $5 \mathrm{~mL}$ aceton. Proses pencampuran dilakukan dengan pengadukan menggunakan magnetic stirrer dengan kecepatan putar $500 \mathrm{rpm}$ selama 60 menit agar diperoleh larutan yang homogen. Selanjutnya dilakukan penyaringan untuk memperoleh batas maksimum ukuran partikel yang diinginkan dengan menggunakan kertas saring Whattman no. 42 (batas maksimum ukuran $2 \mu \mathrm{m}$ lolos kertas saring). Tahap berikutnya adalah proses evaporasi untuk memisahkan pelarut (aseton) dengan zat terlarut (klorofil Spirulina sp) menggunakan evaporator molekular yang diset dengan tekanan $0,05 \mathrm{MPa}(375 \mathrm{mmHg})$ dengan temperatur $45^{\circ} \mathrm{C}$ selama 10 menit.

Tahap pemurnian lebih lanjut dilakukan proses kromatografi. Silica gel (maksimum ukuran butiran $30 \mu \mathrm{m}$ ) sebanyak 30 gr digunakan sebagai elemen fase diam dengan pelarut adalah N-heksan sebanyak $100 \mathrm{~mL}$. Sementara fase gerak merupakan larutan Spirulina sp. Hasil kromatografi berupa larutan klorofil hasil pemurnian sebagai bahan baku lapisan dengan spin coating. Hasil kromatografi juga dilakukan evaporasi kembali pada temperatur $60^{\circ} \mathrm{C}$ dan tekanan 0,05 MPa (375 mmHg) hingga diperoleh gel klorofil spirulina. Gel klorofil ini kemudian di larutkan dalam kloroform merupakan modifikasi lain larutan untuk membuat lapisan.

Larutan yang diperoleh dari proses kromatografi (sebelum evaporasi kedua) dan larutan setelah evaporasi kedua ditumbuhkan pada substrat $\mathrm{Cu}$ berpola dengan spin coater (Chemat 


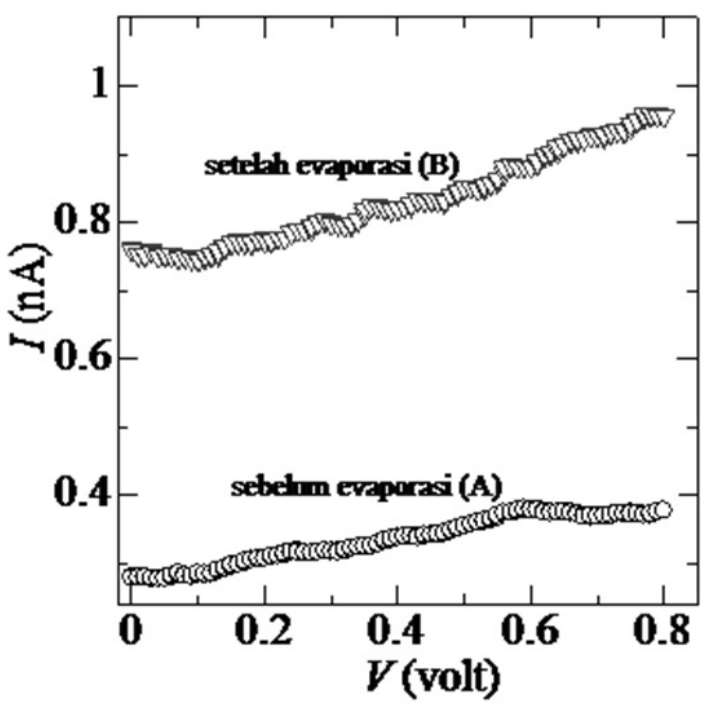

Gambar 1: Karakterisasi I-V lapisan klorofil Spirulina sp untuk modifikasi larutan hasil kromatografi/sebelum evaporasi kedua (sampel A) dan setelah evaporasi selama 10 jam (sampel B).

Technology KW-4A). Spin coater di set dengan kecepatan putar $3500 \mathrm{rpm}$ selama 40 sekon. Dilanjutkan dengan post heating padasuhu $70^{\circ} \mathrm{C}$ selama 90 sekon di atas hot plate. Proses penumbuhan lapisan dilakukan berulang hingga jumlah lapis $\mathrm{N}=3$, sehingga diperoleh sampel lapisan sebelum evaporasi kedua (sampel A) dan setelah evaporasi kedua (sampel B).

Karakterisasi dilakukan dengan metode two point probe IV meter yang dipasang medan magnet dengan arah sejajar lapisan Spirulina sp. Sumber tegangan dihubungkan dengan kumparan menyebabkan timbulnya medan magnet yang diukur menggunakan Gaussmeter. Naik turunnya medan magnet dapat diatur melalui tegangan pada sumber. Medan magnet yang diberikan antara $0 \mathrm{~T}$ hingga $0,02 \mathrm{~T}$. Karakterisasi dilakukan berulang untuk sampel yang telah dibuat. Dari hasil pengukuran, diperoleh grafik arus sebagai fungsi tegangan.

\section{HASIL DAN PEMBAHASAN}

Gambar 1 menunjukkan karakterisasi I-V lapisan klorofil Spirulina sp dievaluasi pada temperatur ruang tanpa pengaruh medan magnet. Teramati dengan jelas bahwa arus terukur sampel lapisan setelah proses evaporasi hasil kromatografi (Sampel B) memberikan arus lebih besar dibandingkan sampel lapisan hasil kromatografi tanpa proses evaporasi lanjutan (Sampel A). Hasil ini disumbang oleh homogenitas pembawa muatan setelah proses evaporasi dan konsisten dengan penelitian sebelumnya [6]. Arus yang hadir ketika sampel diberi tegangan eksternal $\mathrm{V}=0$ menunjukkan keberadaan eksitasi termal pembawa muatan intrinsic [7]. Dengan menganggap pembawa muatan mengalir memenuhi kaidah current drift, maka mobilitas pembawa muatan dapat diperhitungan yaitu masing-masing ( $\mu=8,38 \times 10^{-3} \mathrm{~cm}^{2} /$ V.s $)$ untuk sampel A

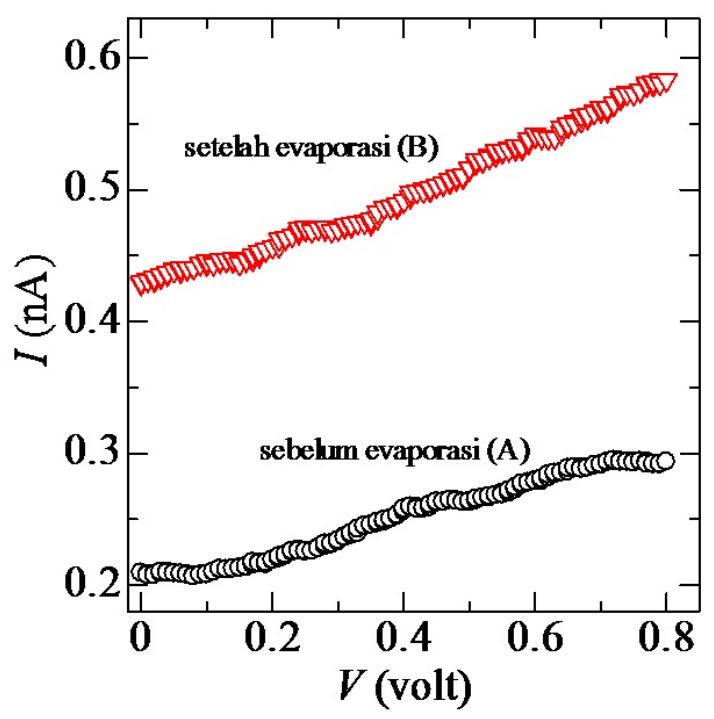

Gambar 2: Karakterisasi I-V lapisan klorofil Spirulina $s p$ untuk modifikasi larutan hasil kromatografi/sebelum evaporasi kedua (sampel A) dan setelah evaporasi selama 10 jam (sampel B) dievaluasi dibawah pengaruh medan magnet $\mathrm{H}=10 \mathrm{mT}$.

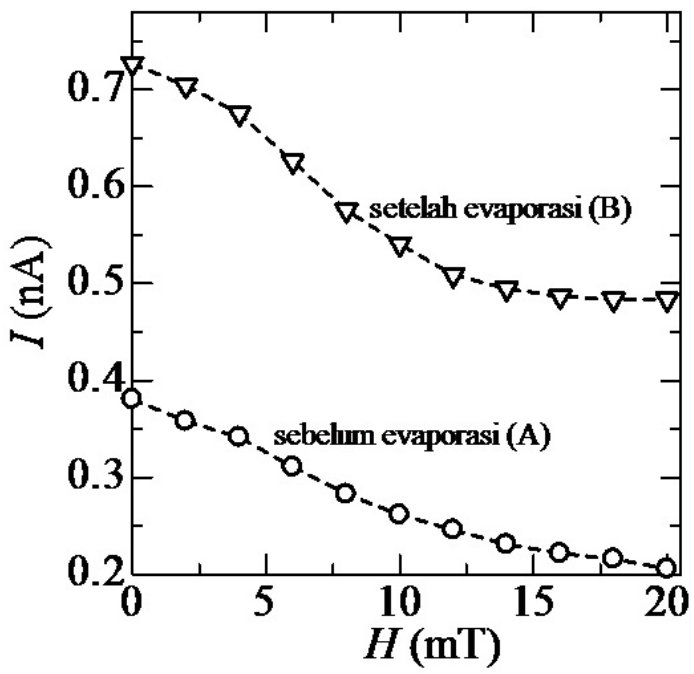

Gambar 3: Karakterisasi perubahan arus I sebagai fungsi medan magnet H lapisan klorofil Spirulina sp untuk sampel A dan sampel B dievaluasi pada $\mathrm{V}=0,4$ volt.

dan $\left(\mu=23,60 \times 10^{-3} \mathrm{~cm}^{2} /\right.$ V.s $)$ untuk sampel B.

Ekspresi lain, yaitu karakterisasi I-V lapisan klorofil Spirulina $s p$ dibawah pengaruh medan magnet $\mathrm{H}=10 \mathrm{mT}$ diperlihatkan pada Gambar 2. Tidak teramati secara drastis perubahan karakteristik I-V dari kedua sampel menunjukkan bahwa pembawa muatan sampel A dan B memiliki respon terhadap medan magnet $\mathrm{H}$ yang sama. Secara umum arus terukur saat medan magnet $\mathrm{H}$ diterapkan adalah lebih kecil dibandingkan tanpa medan. Sebagaimana telah diketahui bahwa pembawa muatan bahan organik secara umum disusun oleh pembawa muatan positif dan negatif. Oleh karena itu, penurunanan arus 
terukur dapat dikaitkan proses rekombinasi kedua pembawa muatan akibat medan magnet. Mengingat supplai pembawa muatan sama ketika tegangan yang diberikan sama pada nilai tertentu, maka penurunan arus terukur akibat medan dapat disajikan sebagai arus sebagai fungsi medan $\mathrm{H}$ yang dikenal sebagai fenomena magneto-conductance seperti pada Gambar 3.

Teramati secara jelas dari gambar bahwa mula-mula saat medan terpasang nol $(\mathrm{H}=0)$ arus terukur maksimum. Kemudian ketika medan diaplikasikan, arus mulai mengalami penurunan hingga mencapai keadaan yang konstan. Artinya pasangan pembawa muatan positif dan negatif sudah tidak mengalami rekombinasi kembali. Karakteristik ini teramati sama untuk kedua sampel. Untuk sampel A, medan mulai konstan pada kisaran $\mathrm{H}=18 \mathrm{mT}$ sementara untuk sampel setelah evaporasi medan mulai konstan pada $\mathrm{H}=14 \mathrm{mT}$. Tingkat kemurnian dan homogenitas pembawa muatan dipandang se- bagai penyebab perbedaan ini. Rasio MC ( $\left.=\frac{I_{\circ}-I(H)}{I}\right)$ untuk sampel sebelum dan setelah evaporasi sebesar $37,4 \%$ dan $50,6 \%$.

\section{SIMPULAN}

Efek medan magnet terhadap pembawa muatan lapisan Spirulina $s p$ hasil karakterisasi I-V meter telah dilakukan. Hasil pengukuran magneto konduktansi menunjukkan bahwa medan yang diperlukan untuk mencapai nilai arus terukur konstan pada sampel B lebih kecil dari sampel A. Hal ini mengindikasikan tingkat kemurnian dan homogenitas berpengaruh pada mekanis merekombinasi pasangan pembawa muatan. Akhirnya rasio MC 37,4\% dan 50,6\% diperoleh untuk masing-masing sampel A dan sampel B.
[1] A. Kohler, H. Bassler, J. Materials Science and Engineering R, 66, 71-109 (2009).

[2] F.L. Bloom, et al., Physical Review Letter, 99, 257201 (2007).

[3] L. Chen, et al., J. Material Chemistry C, 1-6 (2015).

[4] M. Cox, et al., Physical Review B, 89, 195204 (2014).

[5] E. Fionita, dkk., Jurnal Fisika dan Aplikasinya, 10(2), 99-102
(2014).

[6] Supatmi, Utari, B. Purnama, Jurnal Fisika dan Aplikasinya, 12(1), 21-23 (2016).

[7] Podzorov, et al., Physics Review Letter, 93(8), 086602 (2004). 